\title{
TIME RELATIONSHIPS OF THE WOOD-TICK IN THE TRANSMISSION OF ROCKY MOUNTAIN SPOTTED FEVER.*
}

\author{
JoSIAH J. MOORE.
}

(From the Pathological Laboratory of the University of Chicago.)

The chief object of the following experiments, undertaken at the suggestion of the late Dr. Howard T. Ricketts, was to determine (I) the minimum duration of feeding by infected tick necessary to infect the guinea-pig; (2) the minimum duration required for the infection of the tick from the infected guinea-pig; and (3) the length of the incubation period in the tick, that is, the period of time required for the etiological factor to establish itself in the tick and render it infective.

Duration of feeding by infected tick necessary to infect the guineapig.-All the ticks used in this experiment were bred in the laboratory in tick-proof cages. They were of two species, Dermacentor venustus and Dermacentor modestus. The parents of the former were the second generation of that species raised in the laboratory, the original ancestors having been procured from the Bitter Root Valley in Montana in the spring of 1907 . These had been infected in the usual manner with the Montana strain of fever and had transmitted this from generation to generation up to the present time. ${ }^{x}$ The parents of the latter species (Dermacentor modestus) were collected in Idaho in the spring of 1909 and these also were infected with the Montana strain.

The method was as follows: In the group of experiments in Table I, the tick was first permitted to feed for five or ten days on a normal guinea-pig to test its infectivity. After making sure that it was infected, the tick was removed and kept at room temperature for a variable period; then fed on a normal guinea-pig for a certain number of hours; again removed and kept at room temperature. The feedings were repeated at variable intervals on new guineapigs until the tick died.

* Received for publication October $\mathbf{~}$, 1910.

× Ricketts, H. T., Jour. Am. Med. Assn., I007, 49, p. I 278. 
TABLE I.

Duration of Trek-Feeding Required for the Infection of the Gunea-Pig.

Ticks previously tested and proved infective.

\begin{tabular}{|c|c|c|c|c|c|c|c|c|c|}
\hline Exper & $\begin{array}{l}\text { Tick Species } \\
\text { and Number }\end{array}$ & $\begin{array}{c}\text { End of } \\
\text { Infectivity } \\
\text { Test }\end{array}$ & Interval & $\begin{array}{c}\text { Length of } \\
\text { First Test } \\
\text { and } \\
\text { Date }\end{array}$ & 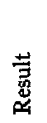 & 苞 & $\begin{array}{c}\text { Length of } \\
\text { Second } \\
\text { Test } \\
\text { and Date }\end{array}$ & $\begin{array}{l}\text { 苟 } \\
\stackrel{4}{4}\end{array}$ & 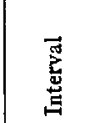 \\
\hline & $\begin{array}{l}\text { D. modestus } \\
\text { F. 90 }\end{array}$ & $9 / 15$ & days & ${ }_{9 / \mathrm{I} 8}^{\mathrm{I8} \mathrm{hr} .}$ & + & 4 days & $\begin{array}{c}10 \mathrm{br} . \\
9 / 22\end{array}$ & $t$ & 16 days \\
\hline $\begin{array}{l}\text { II.. } \\
\text { III. . }\end{array}$ & $\begin{array}{l}\text { D. venustus } \\
\text { M. Io6 } \\
\text { D. modestus } \\
\text { M. roo }\end{array}$ & $\begin{array}{l}9 / 15 \\
10 / 5\end{array}$ & $\begin{array}{l}7 \text { days } \\
\text { I7 days }\end{array}$ & $\begin{array}{l}\text { r hr. } \\
9 / 22 \\
\text { IO hr. } \\
\text { IO/22 }\end{array}$ & - & $\begin{array}{l}4 \text { days } \\
4 \text { days }\end{array}$ & $\begin{array}{r}5 \mathrm{hr} . \\
9 / 25 \mathrm{hr} \\
\mathrm{I0} / 26\end{array}$ & -1 & $\begin{array}{c}\text { tick dead } \\
9 / 27 \\
\text { I3 days }\end{array}$ \\
\hline IV... & $\begin{array}{l}\text { D. modestus } \\
\text { F. } 87\end{array}$ & $9 / 2 I$ & 43 days & $\mathrm{Ir} / 3^{5 \mathrm{hr} .}$ & + & 8 days & $\begin{array}{r}2 \frac{1}{2} \mathrm{hr} . \\
\mathrm{II} / \mathrm{II}\end{array}$ & - & Ig days \\
\hline V.. & D. modestus & $9 / 20$ & 44 days & $\mathrm{Ir} / 3^{5 \mathrm{hr}}$ & + & 8 days & II $/ \mathbf{I I} \mathrm{hr}$ & - & I9 days \\
\hline VI.. & $\begin{array}{l}\text { D. venustus } \\
\text { F. I98 }\end{array}$ & $10 / 25$ & 9 days & $\mathrm{II} / 4^{5 \mathrm{hr}}$ & - & 26 days & $\mathrm{I}_{2} / \mathrm{r}^{5 \mathrm{hr}}$ & - & I 2 days \\
\hline VII. & D. venustus & $10 / 25$ & 9-ro days & II $/ 4$ hr. & - & I8 days & $\begin{array}{l}5 \mathrm{hr} \\
\mathrm{II} / 22\end{array}$ & - & 20 days \\
\hline VIII. & D. venustus & $I I / 2$ & Io days & $\underset{I I / I 2}{5} \mathrm{hr}$. & - & 20 days & $11 / 2 \mathrm{hr}$. & - & tick dead \\
\hline IX... & $\begin{array}{l}\text { D. Venustus } \\
\text { F. } 203\end{array}$ & $\mathrm{II} / \mathrm{I} 6$ & I4 days & $5 \mathrm{x} / 30 \mathrm{hr}$. & - & I4 days & $\begin{array}{r}15 \mathrm{hr} . \\
\mathrm{I} 2 / \mathrm{I} 4\end{array}$ & - & $\underset{12 / 26}{\text { tick dead }}$ \\
\hline $\mathbf{X}$ & $\begin{array}{l}\text { D. venustus } \\
\text { M. } 204\end{array}$ & II/ T9 & I 3 days & I $2 / 2^{5 h r}$ & - & 21 days & $\begin{array}{l}20 \mathrm{hr} \\
\mathrm{I} 2 / 23\end{array}$ & - & I5 days \\
\hline XI. . . & $\begin{array}{l}\text { D. modestus } \\
\text { F, 103 }\end{array}$ & $10 / 18$ & 37 days & I $2 / 8^{5 \mathrm{hr}}$ & - & I7 days & $\begin{array}{l}\text { Io hr. } \\
\mathrm{I} 2 / \mathrm{rg}\end{array}$ & + & $\begin{array}{c}\text { tick dead } \\
2 / 23\end{array}$ \\
\hline XII.. & $\begin{array}{l}\text { D. modestus } \\
\text { F. 108 }\end{array}$ & $r 1 / 28$ & Io days & $\mathrm{I}_{2} / 8^{5 \mathrm{hr}}$ & - & \begin{tabular}{|} 
tick dead \\
$12 / 12$
\end{tabular} & $\cdots \cdots$ & $\cdots$ & $\cdots \cdots$ \\
\hline XIII.. & D. modestus & II $/ 22$ & 25 days & $\begin{array}{l}5 \mathrm{hr} . \\
\mathrm{I} 2 / \mathrm{I} 7\end{array}$ & + & ays & $r / 0^{8 \mathrm{hr} .}$ & + & I9 days \\
\hline XIV.. & D. modestus & $I I / 28$ & I9 days & Is hr. & - & 20 days & $\begin{array}{l}20 \mathrm{hr} \text {, disc } \\
\text { ed } \mathrm{r} / \mathrm{To}\end{array}$ & ard- & I6 days \\
\hline XV. & D. modestus & $I I / 29$ & 21 days & $\begin{array}{r}\text { I5 hr. } \\
\text { I } / 20\end{array}$ & + & 21 days & Io(P) hr. di & scar- & 20 days \\
\hline XVI. . & $\begin{array}{l}\text { D. modestus } \\
\text { F. 105 }\end{array}$ & $11 / 22$ & 31 days & $\begin{array}{r}3-5 \mathrm{hr} . \\
\mathrm{r} 2 / \mathrm{x}^{3}\end{array}$ & - & I 5 days & $\mathrm{I} / 7^{5 \mathrm{hr}}$ & - & 23 days \\
\hline
\end{tabular}

TABLE 2.

Duration or Tick-Feeding Required for the Infection of the Guinea-Pig.

Ticks not previously tested for infectivity.

\begin{tabular}{|c|c|c|c|c|c|c|}
\hline Experiment & $\begin{array}{l}\text { Tick Species } \\
\text { and Number }\end{array}$ & $\begin{array}{l}\text { Date of } \\
\text { Moulting }\end{array}$ & Interval & $\begin{array}{l}\text { Duration of } \\
\text { First Test } \\
\text { and Date }\end{array}$ & Result & Interval \\
\hline $\begin{array}{r}\text { xVII } \ldots \ldots \ldots \\
\text { xVIII } \ldots \ldots \ldots \ldots \\
\mathbf{x I x} \ldots \ldots \ldots \ldots \\
\mathbf{x x} \ldots \ldots \ldots \ldots\end{array}$ & $\begin{array}{l}\text { D. modestus } \\
\text { F. I28 } \\
\text { D. venustus } \\
\text { M. } 222 \\
\text { D. modestus } \\
\text { M. I 19 } \\
\text { D. modestus } \\
\text { M. I30 }\end{array}$ & $\begin{array}{l}\text { Unknown } \\
\text { Unknown } \\
\text { Unknown } \\
\text { Unknown }\end{array}$ & $\begin{array}{l}\text { Unknown } \\
\text { Unknown } \\
\text { Unknown } \\
\text { Unknown }\end{array}$ & 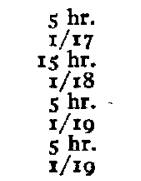 & $\begin{array}{l}- \\
- \\
-\end{array}$ & $\begin{array}{l}18 \text { days } \\
\text { Io days } \\
21 \text { days } \\
23 \text { days }\end{array}$ \\
\hline
\end{tabular}


TABLE 5 .

Duration of Tick-Fendng Required for the Inzection of the Guinea-Pig.

Ticks previously tested and proved infective.

\begin{tabular}{|c|c|c|c|c|c|c|c|c|c|c|c|c|c|}
\hline $\begin{array}{l}\text { Length of } \\
\text { Third } \\
\text { Test and } \\
\text { Date }\end{array}$ & $\stackrel{\vec{z}}{\ddot{z}}$ & 疍 & $\begin{array}{l}\text { Length } \\
\text { of } \\
\text { Fourth } \\
\text { Test } \\
\text { and } \\
\text { Date }\end{array}$ & 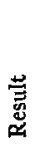 & 焉 & $\begin{array}{l}\text { Length } \\
\text { of } \\
\text { Fifth } \\
\text { Test } \\
\text { and } \\
\text { Date }\end{array}$ & 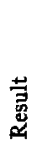 & 蛋 & $\begin{array}{c}\text { Length } \\
\text { of } \\
\text { Sixth } \\
\text { Test } \\
\text { and } \\
\text { Date }\end{array}$ & 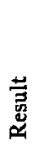 & 丞 & 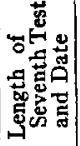 & $\frac{\stackrel{+}{7}}{\stackrel{8}{\mathscr{2}}}$ \\
\hline $\begin{array}{l}\text { I hr. } 45 \mathrm{~m} . \\
\text { Io } / \mathrm{g}\end{array}$ & + & I I days & $\begin{array}{l}6 \text { days } \\
10 / 19^{-} \\
10 / 25\end{array}$ & + & $\begin{array}{c}\text { tick dead } \\
\text { 10/30 }\end{array}$ & $\cdots \cdots$ & $\ldots$ & $\cdots \cdots$ & $\ldots \ldots$ & $\cdots$ & $\ldots \ldots$ & $\cdots$ & . \\
\hline$\ldots \ldots$ & $\cdots$ & $\cdots \cdots$ & $\ldots \ldots$ & $\cdots$ & $\ldots$ & $\ldots \ldots$ & $\cdots$ & $\ldots \ldots$ & $\ldots \ldots$ & $\cdots$ & $\cdots$ & $\cdots$ & $\cdots$ \\
\hline $\begin{array}{l}\text { To hr. } \\
\text { rI } / 9\end{array}$ & - & 22 days & $\begin{array}{l}\text { I I days } \\
\text { I } 2 / x^{-} \\
\text {I } 2 / I_{2}\end{array}$ & + & 28 days & $\begin{array}{l}20 \mathrm{hr} \\
\mathrm{I} / \mathrm{g}\end{array}$ & + & Io days & $\begin{array}{l}\text { Io hr. } \\
\text { Io/Io }\end{array}$ & - & $\ldots$ & $\ldots$ & . \\
\hline $\mathrm{II} / 30 \mathrm{hr}$ & - & $\begin{array}{c}\text { tick dead } \\
I 2 / 5\end{array}$ & $\begin{array}{l}12 / 36 \\
\ldots \ldots\end{array}$ & $\cdots$ & $\ldots \ldots$ & $\ldots \ldots$ & $\cdots$ & $\cdots$ & $\ldots \ldots$ & $\because$ & $\ldots \ldots$ & $\ldots$ & .. \\
\hline $\begin{array}{l}2 \frac{1}{2} \mathrm{br} . \\
\text { II } / 30\end{array}$ & - & tick dead & $\cdots \cdots$ & $\cdots$ & $\ldots \ldots$ & $\cdots$ & .. & - & . & . & . & $\cdots$ & . \\
\hline $\begin{array}{l}\text { ro hr. } \\
\text { 12/13 }\end{array}$ & - & $\begin{array}{c}\text { tick dead } \\
12 / 16\end{array}$ & $\ldots \ldots$ & $\ldots$ & $\ldots$ & . & . & $\ldots \ldots$ & $\ldots \ldots$ & $\cdots$ & $\ldots \ldots$ & $\ldots$ & $\cdots$ \\
\hline $\begin{array}{l}\text { Io } \mathrm{hr} . \\
12 / 13\end{array}$ & - & $\mid \begin{array}{c}\text { tick dead } \\
\text { I2/I8 }\end{array}$ & $\ldots \ldots$ & . & & & $\ldots$ & &. & $\ldots$ & $\ldots$ & $*$ & $\ldots$ \\
\hline$\cdots \cdots$ & . & $\cdots \cdots$ & $\ldots \ldots$ & . & $\ldots \ldots$ & $\ldots \ldots$ & . & $\cdots$ & . & $\cdots$ & $\ldots$ & $\cdots$ & $\cdots$ \\
\hline$\cdots \ldots$ & . & $\ldots \ldots$ & $\ldots \ldots$ & $\cdots$ & $\ldots \ldots$ & $\ldots \ldots$ & . & $\ldots \ldots$ & $\ldots \ldots$ & $\cdots$ & $\ldots$ & $\cdots$ & .. \\
\hline$I / 7^{5 \mathrm{hr}}$ & - & 20 days & $\begin{array}{c}20 \mathrm{hr} . \\
\mathrm{I} / 27\end{array}$ & + & II days & $\begin{array}{l}\text { ro hr. } \\
2 / 7\end{array}$ & - & I 4 days & $\begin{array}{r}\text { Io hr. } \\
2 / 2 \mathrm{I}\end{array}$ & - & $\ldots$ & $\ldots$ & .. \\
\hline$\ldots \ldots$ & $\cdots$ & $\ldots \ldots$ & $\ldots \ldots$ & $\cdots$ & $\cdots \cdots$ & $\ldots \ldots$ & $+\cdot$ & $\ldots \ldots$ & $\cdots \cdots$ & $\cdots$ & $\cdots$ & $\cdots$ & . \\
\hline$\cdots$ & - & $\ldots \ldots$ & $\cdots$ & . & & . & . & $\ldots \ldots$ & $\cdots \cdots$ & $\cdots$ & $\ldots$ & $\cdots$ & . \\
\hline$\frac{5}{5} / 28^{h r}$ & - & $I_{3}$ days & $\begin{array}{l}5 \mathrm{hr} . \\
2 / 9\end{array}$ & - & $\mid \begin{array}{c}\text { tick dead } \\
2 / 20\end{array}$ & & $\cdots$ & & & $\cdots$ & & & $\ldots$ \\
\hline $\begin{array}{l}20 \mathrm{hr} \\
1 / 27\end{array}$ & + & I I days & $\begin{array}{c}\text { Io hr. } \\
2 / 7\end{array}$ & + & $\begin{array}{c}\text { tick dead } \\
2 / 15\end{array}$ & & $\cdots$ & & $\cdots \cdots$ & $\ldots$ & & & $\cdots$ \\
\hline $2 / \mathrm{r}$ & + & 8 days & $\begin{array}{l}5 \mathrm{hr} \\
2 / 9\end{array}$ & + & I4 days & $\begin{array}{l}3 \mathrm{hr} . \\
2 / 23\end{array}$ & $t$ & 9 days & $2 \mathrm{hr}$. & + & 3 days & $\begin{array}{l}\text { I hr. } \\
3 / 7\end{array}$ & - \\
\hline $2 / \mathrm{I}^{5 \mathrm{hr}}$ & + & $\begin{array}{c}\text { tick dead } \\
2 / 10\end{array}$ & $\ldots \ldots$ & $\cdots$ & $\ldots \ldots$ & $\ldots \ldots$ & . & $\cdots$ & $\ldots \ldots$ & $\cdots$ & & $\ldots$ & - \\
\hline
\end{tabular}

TABLE 2.

Duration of Tick-Feeding Required for the Infection of the Guinea-Pig.

Ticks not previously tested for infectivity.

\begin{tabular}{|c|c|c|c|c|c|c|c|}
\hline $\begin{array}{l}\text { Duration of } \\
\text { Second Test } \\
\text { and Date }\end{array}$ & Result & Interval & $\begin{array}{l}\text { Duration of } \\
\text { Third Test } \\
\text { and Date }\end{array}$ & Result & Interval & $\begin{array}{l}\text { Duration of } \\
\text { Fourth Test } \\
\text { and Date }\end{array}$ & Result \\
\hline $\begin{array}{l}5 \mathrm{hr} . \\
2 / 4 \\
15 \mathrm{hr} . \\
1 / 28 \\
15 \mathrm{hr} . \\
2 / 9 \\
20 \mathrm{hr} . \\
2 / 1 \mathrm{Ir}\end{array}$ & $\begin{array}{l}- \\
+ \\
+ \\
+\end{array}$ & $\begin{array}{l}12 \text { days } \\
\text { I } 5 \text { days } \\
16 \text { days } \\
\text { tick dead }\end{array}$ & $\begin{array}{c}15 \mathrm{hr} \\
2 / \mathrm{I} 6 \\
5 \mathrm{hr} . \\
2 / \mathrm{rr} \\
\text { Io }(?) \mathrm{hr} . \\
2 / 25 \\
\ldots \ldots \ldots \ldots\end{array}$ & $\begin{array}{l}- \\
+ \\
- \\
\cdots\end{array}$ & $\begin{array}{c}20 \text { days } \\
12 \text { days } \\
\text { tick lost } \\
\ldots . . .\end{array}$ & $\begin{array}{c}20 \mathrm{hr} . \\
3 / 8 \\
3 \mathrm{hr} \\
2 / 23 \\
\ldots \ldots \ldots\end{array}$ & $\begin{array}{l}+ \\
- \\
\ldots \\
\cdots\end{array}$ \\
\hline
\end{tabular}


In the second group of experiments (Table 2) the ticks were not given a preliminary test, but the first feed was regarded as a time test; in all other respects the experiments were similar.

When testing or feeding an individual tick, the guinea-pig was placed in a pillory and the tick allowed to attach itself to the ear. The time of feeding was taken from the minute the tick became so firmly attached that when the tick body was flipped back it could not be detached from the pig.

In the beginning of the work it was thought that a feeding of one hour would be sufficient to infect a guinea-pig, but it was soon found necessary to extend this period to five hours. If the tick proved infective in the five-hour test the time could be reduced in the second test, or if the infection were not transmitted to the guinea-pig in the first test, the time could be lengthened.

The results of the experiments as shown by the tabular summary of Tables $I$ and 2 are not constant. However, when it is considered that the tick is a living factor, this inconstancy is partially explained. The tick is a slow feeder. The hungriest and most vigorous require from 15 to 20 minutes to attach themselves firmly by means of the palpi, and without this firm attachment feeding is impossible. In other ticks the process is much slower, and after two or three days of attachment there is little evidence of the ingestion of blood.

Table I shows that the minimum duration of tick feeding necessary to infect a guinea-pig was found to be one hour and fortyfive minutes (Experiment I, with Dermacentor modestus, Female 9o). In Experiment XV, D. modestus, Female I 10 , was infected in a two-hours' feed and again in a three-hours' feed. A five-hours' feed inoculated in Experiments IV, V, XIII, XV, XVI, and XVIII; an eight-hours' in Experiment XII; a ten-hours' in Experiments I, $\mathrm{XI}$, and XIV; a fifteen-hours' in Experiments XV (twice), XVIII, and XIX; a twenty-hours' in Experiments III, X, XIV, XVII, and XX. Twenty-seven five-hour tests were tried, and six, or 22 per cent, infected; ten ten-hour tests, of which three, or 30 per cent, infected; eight fifteen-hour tests, in which four, or $5 \circ$ per cent, were positive; six twenty-hour tests, with five, or 83 per cent, positive; nine one- to three-hour tests and three, or 33 per cent, infected. To 
account for the higher percentage of infections in the one- to threehour than in the five-and ten-hour tests we find that in the former cases two highly infected and voracious ticks caused the three inoculations, while in the latter the ticks were apparently not so heavily infected, and were only average feeders.

From the data given it is observed that the average time for infecting the guinea-pig by the wood tick is about ten hours, and that twenty hours is almost surely infective. Only once did this fail, but, on repeating (Experiment $\mathrm{X}$ ), a positive result was obtained.

D. modestus, Female 90 and Female Iro, gave the best results, infecting the animals upon which they were tested at practically each feed. In Experiment XIII the first five-hours' feed was positive, while two others repeated later at varying intervals did not cause infection. The results obtained in this experiment, in Experiment XVI, and also in Experiment XVII, where, after a negative fifteen-hours' test there followed positive twenty-and fivehour tests, may have been due to disinclination of the tick to feed vigorously. In Experiments I and III the weakened condition of the ticks necessitated long feeds to restore their vitality.

From the tabulated summary it appears that both males and females of the modestus species gave more positive results than those of the venustus. This was probably due to the fact that the former were younger and more vigorous and therefore fed more rapidly.

Duration of feeding required for the infection of the tick and length of incubation period in the tick.-The technic in this series of experiments was as follows: A number of normal ticks were allowed to feed on an infected guinea-pig for a definite number of hours; they were then removed and kept at room temperature for several days, when feeding was again permitted, this time, however, on a normal guinea-pig, for a definite period. Both species, D. venustus, and $D$. modestus, were tested. The infected guinea-pigs on which the ticks were fed were regular passage animals, and were used between their second and fifth days of fever.

In only two of the 27 was the spotted fever virus demonstrated in the tick, so that the results cannot be considered conclusive. It seems highly probable that a much shorter feed is required for 
TABLE 3 -

Duration of Feedinc Necessary to Infect Tick and Incubation Period in the Tick.

\begin{tabular}{|c|c|c|c|c|c|c|c|c|c|c|c|}
\hline Exp. & $\begin{array}{l}\text { Tick Species } \\
\text { and Number }\end{array}$ & $\begin{array}{l}\text { Date of } \\
\text { Feeding }\end{array}$ & $\left|\begin{array}{c}\text { Length } \\
\text { of } \\
\text { Feeding }\end{array}\right|$ & $\begin{array}{c}\text { Inter- } \\
\text { val }\end{array}$ & $\begin{array}{c}\text { Date } \\
\text { of Test }\end{array}$ & $\begin{array}{l}\text { Length } \\
\text { of Test }\end{array}$ & $\begin{array}{l}\text { Re- } \\
\text { sult }\end{array}$ & $\begin{array}{l}\text { Inter- } \\
\text { val }\end{array}$ & $\begin{array}{l}\text { Date of } \\
\text { Second } \\
\text { Test }\end{array}$ & $\begin{array}{l}\text { Length } \\
\text { of Test }\end{array}$ & $\begin{array}{l}\text { Re- } \\
\text { sult }\end{array}$ \\
\hline I. . . . & $\begin{array}{l}\text { D. venustus } \\
\text { M. } 204 \\
\text { M. 205 } \\
\text { F. 206 } \\
\text { M. 207 } \\
\text { M. 208 } \\
\text { F. 209 } \\
\text { M. } 210 \\
\text { M. 21 } \\
\text { F. 21 } 2 \\
\text { D. venustus } \\
\text { M. 214 } \\
\text { M. 215 } \\
\text { M. 216 } \\
\text { F. 217 } \\
\text { F. 218 } \\
\text { M. 219 } \\
\text { F. 220 } \\
\text { M. 221 } \\
\text { D. venustus } \\
\text { M. 225 } \\
\text { M. 226 } \\
\text { D. modestus } \\
\text { M. I68 } \\
\text { M. I73 } \\
\text { M. I74 } \\
\text { D. venustus } \\
\text { F. 232 } \\
\text { D. modestus } \\
\text { F. I78 } \\
\text { F. I79 }\end{array}$ & $\begin{array}{l}12 / 5 \\
12 / 5 \\
12 / 5 \\
12 / 5 \\
12 / 5 \\
12 / 5 \\
12 / 5-6 \\
12 / 5-6 \\
12 / 5-6 \\
1 / 9 \\
1 / 9 \\
1 / 9 \\
1 / 9-10 \\
1 / 9-10 \\
1 / 9-10 \\
1 / 9-10 \\
1 / 9-10 \\
1 / 24 \\
1 / 24 \\
3 / 1-2 \\
3 / 1-2 \\
3 / 1-2 \\
3 / 24-25 \\
3 / 24-30 \\
3 / 29-30\end{array}$ & $\begin{array}{l}5 \text { hrs. } \\
5 \text { hrs. } \\
5 \text { hrs. } \\
\text { I } 0 \text { hrs. } \\
\text { Io hrs. } \\
\text { I0 hrs. } \\
20 \text { hrs. } \\
20 \text { hrs. } \\
20 \text { hrs. } \\
\text { 10 hrs. } \\
\text { 10 hrs. } \\
\text { 10 hrs. } \\
20 \text { hrs. } \\
20 \text { hrs. } \\
20 \text { hrs. } \\
25 \text { hrs. } \\
25 \text { hrs. } \\
25 \text { hrs. } \\
25 \text { hrs. } \\
25 \text { hrs. } \\
40 \text { hrs. } \\
40 \text { hrs. } \\
25 \text { hrs. } \\
25 \text { hrs. } \\
25 \text { hrs. }\end{array}$ & $\begin{array}{l}7 \text { days } \\
14 \text { days } \\
\text { tick died } \\
7 \text { days } \\
13 \text { days } \\
39 \text { days } \\
6 \text { days } \\
13 \text { days } \\
39 \text { days } \\
\text { tick died } \\
4 \frac{1}{2} \text { days } \\
25 \text { days } \\
4 \text { days } \\
23 \text { days } \\
41 \text { days } \\
4 \text { days } \\
24 \text { days } \\
37 \text { days } \\
\text { tick died } \\
20 \text { days } \\
\text { 10 days } \\
20 \text { days } \\
35 \text { days } \\
30 \text { days } \\
38 \text { days }\end{array}$ & 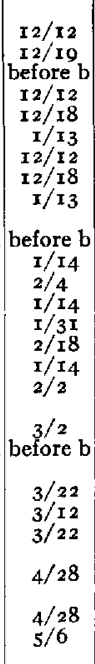 & $\begin{array}{c}\text { ro hrs. } \\
\text { Io hrs. } \\
\text { eing test } \\
5 \text { hrs. } \\
20 \text { hrs. } \\
\text { I } 5 \text { hrs. } \\
20 \text { hrs. } \\
20 \text { hrs. } \\
\text { I } 5 \text { hrs. } \\
\text { eing test } \\
20 \text { hrs. } \\
20 \text { hrs. } \\
20 \text { hrs. } \\
\text { I } 5 \text { hrs. } \\
\text { I } 5 \text { hrs. } \\
20 \text { hrs. } \\
\text { I } 5 \text { hrs. } \\
20 \text { hrs. } \\
\text { eing test } \\
20 \text { hrs. } \\
20 \text { hrs. } \\
20 \text { hrs. } \\
25 \text { hrs. } \\
30 \text { hrs. } \\
25 \text { hrs. }\end{array}$ & $\begin{array}{l}\bar{z} \\
\text { ed } \\
\overline{-} \\
\bar{z} \\
\overline{-} \\
\overline{-} \\
\overline{-} \\
\overline{-} \\
- \\
\text { ed }\end{array}$ & $\begin{array}{c}\ldots \\
\ldots \ldots \\
\ldots \ldots \\
\ldots \ldots \\
\ldots \ldots \\
29 \text { days } \\
\ldots \ldots \\
\ldots \ldots \\
\ldots \ldots \\
\ldots \ldots \\
\ldots \ldots \\
\ldots \text { days } \\
\ldots \ldots \\
\ldots \ldots \\
\ldots \ldots\end{array}$ & $\begin{array}{l}\ldots \ldots \\
\ldots \ldots \\
\ldots \ldots \\
\ldots \ldots \\
\ldots \ldots \\
2 / 2 \\
\ldots \ldots \\
\ldots \ldots \\
\ldots \ldots \\
\ldots \ldots \\
\ldots \ldots \\
2 / 18-3 \\
\ldots \ldots \\
\ldots \ldots \\
\ldots \ldots \\
\ldots \ldots \\
\ldots \ldots \\
\ldots \ldots \\
\ldots \ldots \\
\ldots \ldots\end{array}$ & 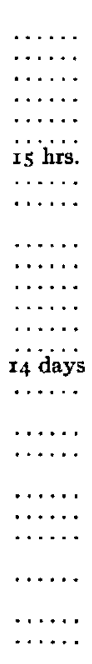 & $\begin{array}{c}\because \\
\because \\
\because \\
\ddot{+} \\
\cdots\end{array}$ \\
\hline
\end{tabular}

infection and that the incubation period in the tick is shorter than is indicated by these experiments. The complete protocols of the two tests in which complete results, as indicated by the transmission of the disease by the tick to the normal guinea-pig, were obtained, follow.

$D$. venustus, Female 220 , was attached to infected guinea-pig 2,547 for 25 hours on January 9-10. No hyperemic area was observed around the bite and no feces were passed. On January I4, after an interval of four days, it attached itself to normal guinea-pig $2,7 \mathrm{I}_{3}$ and was removed after 20 hours. The tick did not appear to feed much, not increasing any in size, and passing no feces. The temperature of guinea-pig 2,7 13 was taken for two weeks but did not rise above 103.4 F. A month later, February 27 , the pig was given an immunity test of $\mathbf{I}$ c.c. of blood from an infected pig. It became infected and died, the organs showing changes typical of spotted fever. This proved conclusively that the guinea-pig had not been infected by the tick, since Ricketts and Gomez $z^{2}$ have shown that one attack of spotted fever renders the guineapig immune to a second inoculation.

On February 18, Female 220 attached itself to normal guinea-pig 2,779. It was found off March 5, having been attached for 15 days. It had increased markedly in size during the feeding. A hyperemic area about $2 \mathrm{~cm}$. in diameter was observed around the bite.

'Jour. Infect. Dis., I 908,5, p. $22 \mathrm{I}$. 
TEMPERATURE OF GUINEA-PIG 2,779 .

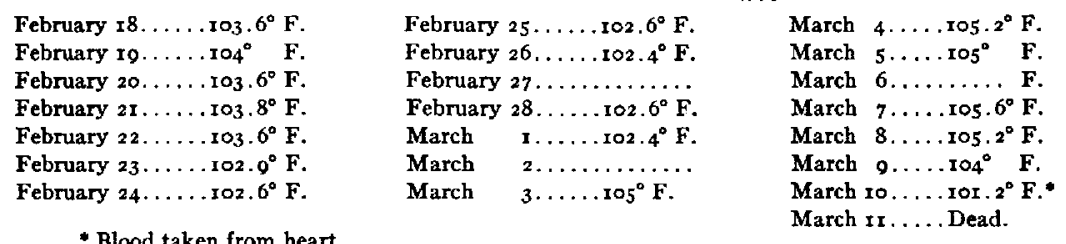

- Blood taken from heart.

Autopsy.-Axillary glands enlarged and congested. Spleen twice the normal size and of a deep, bluish-red color. The heart, lungs, and intestines normal. The suprarenal glands and liver slightly enlarged and congested. The external genitals swollen and the skin slightly hemorrhagic.

Diagnosis.-Spotted Fever. Blood drawn from the heart on March ro was inoculated into guinea-pig $2,83 \mathrm{I}$, which ran a typical spotted-fever temperature. The scrotum became swollen, the ears became necrotic and finally sloughed off. The guinea-pig recovered and later was given an immunity test during which its temperature remained normal. All these facts prove beyond doubt that guinea-pig 2,779 had spotted fever.

In most instances it has been found that an infected tick will produce the fever in a guinea-pig after an incubation period in the pig of five or six days. In the present case this is doubled. Two assumptions may explain the results: ( $\mathrm{r}$ ) either the tick did not feed for several days after becoming attached to guinea-pig 2,779; or (2) the amount of virus ingested by the tick in its feed upon infected guinea-pig 2,547 may have been exceedingly small, since the tick did not feed actively, as is shown by the absence of a hyperemic area around the bite, and this small quantity of virus may not have increased in the body of the tick sufficiently to infect a guinea-pig until the tick had enjoyed for some days what we may regard as a very favorable condition of attachment to a guinea-pig.

On March 29 D. modestus, Female 178 , attached itself to the ear of infected guinea-pig 2,77I, where it was allowed to remain for 25 hours. Considerable feces were passed by the tick, and a slight hemorrhagic area surrounded the bite. After an intermission of 30 days during which the tick was transferred from Chicago to Montana, it attached itself on April 28 to normal guinea-pig 3,004, being removed after 30 hours. On May 5 the temperature of the guinea-pig rose to $104^{\circ} \mathrm{F}$.

TEMPERATURE OF GUINEA-PIG 3,004 .
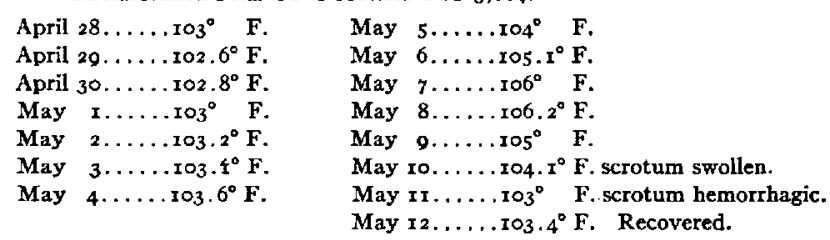
An immunity test was given May 16, but no fever resulted, showing that guineapig 3,004 had been infected the first time. The incubation period in the tick in this case was 30 days with a minimum duration for infecting the tick of 25 hours. With D. modestus, Female 179 , which was attached the same length of time as Female 178 on guinea-pig $2,77 \mathbf{1}$, but was given a 25 -hour test after an interval of 38 days, a negative result was obtained.

In previous experiments the duration of feeding required for the infection of the tick was shown to be less than was found here, 20 hours being the shortest period. ${ }^{x}$ The incubation period is, perhaps; "represented only by the time required for the distribution of the virulent organisms throughout the tick's body and eventually into its salivary glands. In a number of instances the tick proved virulent immediately following its removal from the infected animal" (Ricketts). ${ }^{2}$ In the latter cases, however, the tick was permitted to feed for several days on the infected guinea-pig and thus the incubation period may have been reduced by the tick's remaining attached to the guinea-pig, or it may be that the chances that the tick will infect the susceptible guinea-pig are greatest immediately after its proboscis has been contaminated by feeding on an infected animal.

More experiments will have to be performed before any definite statements can be made relative to the length of the incubation period in the tick. The great number of negative results may have been due to the fact that the ticks were raised under artificial conditions and did not feed as rapidly as those obtained from nature. It will probably be found that ticks taken directly from the woods will give better results. Similar experiments with fresh ticks were to be undertaken in the field during the spring of rgro, but the unfortunate death of Dr. Ricketts prevented the carrying-out of the work. It will, however, probably be completed at some future date.

\section{SUMMARY.}

The minimum duration of feeding necessary for a tick to infect a guinea-pig was found to be one hour and forty-five minutes. The average time necessary seems to be about ten hours, while twenty

I Ricketts, H. T., Jour. Am. Med. Assn., 1907, 49, p. 24.

'Med. Record, s909, 76, p. 843 . 
Time Relationship of Wood-Tick in Spotted Fever 347 hours were almost constantly infective. The duration of feeding necessary to infect a tick is approximately twenty-five hours, while the minimum incubation period in the tick was not definitely determined. With ticks obtained from nature it is possible that the duration of feeding necessary to infect the tick and the incubation period in the tick will be found to be much less than is indicated here. 